\title{
Using social media analytics: The effect of President Trump's tweets on companies' performance
}

\author{
Ahmad H. Juma'h ${ }^{a}$ and Yazan Alnsour ${ }^{a}$ \\ ${ }^{a}$ University of Illinois Springfield, USA
}

\begin{abstract}
Social media is becoming one of the main sources of unstructured data. Many financial analysts use Twitter to gather data and obtain meaningful insights. Recently, high-profile politicians like President Trump have been using Twitter to communicate with the public. The President's Tweets are used as considered to be informative signals that may influence consumers and affect investors' decisions in the stock market. The effect of these signals can be measured by coinciding changes in the stock market or changes in the share prices of certain companies targeted in the President's Tweets. The Tweets used in this research include keywords that are related to finance and economics, public policy, political considerations, and targeted companies. Event study methodology is used to determine the relationship between Trump's Tweets' content and daily changes in major indexes and targeted companies' excess returns. Although many of the recent discussions have indicated that Trump's microblogging can affect the financial markets, the results, on average, show no significant effect of Trump's Tweets on either market indexes nor on most of the targeted companies share prices.
\end{abstract}

Keywords: Unstructured-data analysis, social media, microblogging effects, president's tweets, companies performance

JEL codes: G40, D80 


\section{Introduction}

Advancing research in Management Information System (MIS) has been influenced by psychology, economics, finance, accounting, behavioral research, and other disciplines. Accounting and financial information released through traditional reports are sources of information for managers and investors. This information is then made public for specific periods and for specific purposes. Therefore, there is a need to explore different types of non-mandatory disclosures that are useful for timely decision-making. The web pages of companies and different news agencies are examples of other sources of information used by decision makers (O'Reilly, 1982). Online social media and unstructured data available on the Internet can also be useful information (Gabrovšek et al., 2017). Examples of information that can be found on online social media include customers' satisfaction and experience, quality of products and services, and social-political issues and debates. New information obtained from social media can be used to explain and predict changes in some economic and commercial indicators such as companies' performance (Bollen et al., 2011; Schumaker \& Chen 2009b, 2009a).

Many countries' political leaders are using social media as one of the key platforms to deliver messages to the public. Current (45th) President of the U.S.A., Donald J. Trump, has posted more than 35.9 thousand Tweets on his official account (@ realDonaldTrump) and had about 39.5 million followers as of September $2017^{1}$. The President of the United States has political influences and executive powers; and it is often assumed that the U.S. President has access to information provided by different governmental institutions, financial agencies, and advisors. Therefore, the information shared through the President's Tweets can be used as a forecast to changes in the U.S. economy, financial markets, and targeted companies.

In the globalization era, the U.S. economy, the world's largest, influences most of the economies of the developed and developing countries. For example, the U.S. financial crisis of 2007-2008 had negative effects on the global economy (Francis et al., 2015). The contractions in the U.S. financial conditions such as monetary and fiscal policies, and uncertainty in the financial markets affect global financial markets; especially emerging market and developing economies that depend on external financing (Kose et al., 2017). The following citation from the Economist shows how Trump's political and economic policies affect the rest of the world.

"Mr Trump may kick into reverse a process of globalisation which had already stalled. That will not restore to workers a golden age of prosperity and security. Instead, it will increase the extent to which the global economy feels like a zero-sum competition, increasing the risk of political conflict. It will also destroy a developmental ladder which had already been looking quite rickety. Developing

${ }^{1}$ https://twitter.com/realdonaldtrump (retrieved on 9/29/2017) 
economies will find themselves less able to use trade to boost their growth potential and less able to send migrants to richer countries. At the same time, the international cooperation that occasionally provided some cushion against financial or economic hardship in the developing world could break down" (Economist, 2016).

Tafti, Zotti, and Jank (2016) state that although social media is one of the sources of information about companies' financial conditions, it is hard to capture the effects of the financial information released in social media outlets such as Twitter. On the other hand, the high-frequency stock trading market does not lack the efforts to understand better the information released on social media. Through conducting an analysis of Tweets, the results can be used as indicators in predicting stock prices. One of the known examples of short stock predictions by analyzing Tweets is claimed by an advertising company in Austin, Texas ${ }^{2}$. A software product monitors the President's Tweets, extracts the Tweets, and when a specific company is mentioned, an algorithm decides to shorten the stocks in real time based on in the sentiment analysis of the Tweets demonstrates a negative sentiment. However, how well the algorithm performs on long-term is not disclosed. On the other hand, others' claims that the President's Tweets result in some volatility in stock prices is unquestionable, but no model or algorithm using the President's Tweets has been shown to be consistently supportive of the predictions in trading (Stewart 2017). Appendix A lists a set of selected articles, some in favor and some in contra of the idea of considering the President's Tweets as a reliable source of information in stock trading.

To explore the influence of the content of the U.S. President's Tweets on the targeted companies' financial performance, the study is organized as follows: The next section discusses the theoretical background, Section 3 describes the analysis of the President's Tweets and the statistical methods used, Section 4 presents the main results, and the last section discusses the main conclusions, limitations of the research and further research suggestions.

\section{Literature review}

Financial and non-financial information can influence the nature and magnitude of investors' investments in local or global financial markets. Non-financial information includes announcements by companies about their activities such as entering new markets, introducing new products or services, engagement into alliances or strategic agreements.

The financial statements and accompanying notes as mandatory information by generally accepted accounting principles (GAAP) are an important source of information for all stakeholders (EY, 2014). However, the non-mandatory

${ }^{2}$ https://www.t-3.com/works/the-trump-and-dump-bot/ (retrieved on 9/29/2017) 
information can assist stakeholders in determining the companies' performance. The non-mandatory information includes the voluntary information released by companies in different media sources such as their official web pages, executives' personal web pages and social media, and other information released in social media such as Twitter (Alexander \& Gentry, 2014). This includes any political figures that could influence stock markets globally.

The classic financial theory focuses mainly on explaining the relationship between risk and return. Kendall and Hill (1953) evaluated 19 British indexes during the period 1928-1938 and suggested the existence of a systematic effect on the changes in indexes prices. Markowitz $(1952 ; 1959)$ portfolio theory assumes a relationship between risk and return. These normative theories measure risk by the standard deviation of share prices. There are two classical viewpoints in accounting and finance practices: the organizational view that relates to economic decisions of the entity and market finance that relates to aspects of markets and investments (Asquith \& Weiss, 2016).

In reducing risk and maximizing profits, the analysis of mean-variance of an asset portfolio diversification is used by Markowitz $(1952 ; 1959)$. This approach assumes that investors are risk-averse and prefer safe investments. The works of Markowitz (1952; 1959) contributed to the development of the Capital Asset Pricing Model (CAPM) (Sharpe, 1964; Lintner, 1965; Mossin, 1966; Jensen et al., 1972). The riskfree active variable proposed by Tobin (1958) is incorporated in the CAPM, and it applies to the diversification of optimal portfolios of the market.

Classical accounting and finance theories need to consider the new era of information technology, for example, social media effects on the reporting of financial performance which can generate opportunities and challenges for companies. The Security and Exchange Commission (SEC) regulations may limit the management in using the social media (Alexander \& Gentry, 2014). The social network analysis can be applied to new areas of research in accounting and information systems (Worrell et al., 2013). By analyzing users' textual communications on Twitter or Facebook, companies are able to understand the sentiments of customers (Kim, 2015).

The capital structure and the relevance propositions are essential concepts in the development of accounting and finance theories and practices. The relevance assumptions are linked to equity and debt relationship, to maximize the company value considering the cost of capital (Vargas \& Corredor, 2011). Finance theories and practices rely on the efficient market assumptions: capital market free operations, neutrality of the income tax on natural persons, competitive markets, uniform market access, homogeneous expectations, no bankruptcy costs and no information costs (Modigliani \& Miller, 1958). Miller and Modigliani (1961) 
integrated into their model the dividends policy, the growth and the share valuation of a company.

The equilibrium price of equity at a specific date in a competitive market occurs when the available supply of the equity is equal to the aggregate demand. The equity price reflects a consensus of all the participants in the stock market about the value of the equity based on all publicly available information. The assumption of a perfect capital market is that all available information is freely available to everyone, there are no transaction costs, and all market participants are price takers. Therefore, the simultaneous and complete disclosure of available information leads to consistent expectations with all information incorporated in the spot price (Fama \& Miller, 1972). The real importance of the efficient market hypothesis is whether it is sufficiently valid to afford a practical basis for studying the behavior of share prices. Fama (1970) suggests three levels of market efficiency, namely the weak, the semistrong and the strong form.

Weak form efficiency refers to the information subset consisting of past prices or returns. Weak efficiency is achieved when all information contained in past share price data is fully reflected in current prices. Semi-strong form efficiency refers to the information subset that is publicly available. It suggests new information is rapidly reflected in share prices. Therefore, current prices fully reflect all public information about the company and excess returns cannot be expected unless the investor has inside information which is not yet public. Under semi-strong efficiency, it should not be possible to make returns in excess of the market average by investing subsequent to the release of new information. Strong form efficiency refers to an information subset that contains all information whether publicly available or not and suggests that stock prices reflect all this information. This is because analysts and others involved in the stock market have rational expectations and process trade based and other information to price securities efficiently. Share prices, therefore, include all 'best guess' information and no excess returns can be made from inside information.

The stock market is influenced by macroeconomics, regulations, speculations, among many other factors. The general opinion and investors' sentiment, what they think about an event or a company, influence companies' share prices. The investors' sentiment can be understood through the content of Tweets (Corea, 2016). For example, a large number of negative comments and sentiments in Tweets that targets a specific company might predict a future decline of its revenue (Alles \& Gray, 2016) and imply a negative effect of share prices.

For event study analysis, the approach involves computing returns on the common stock of companies making announcements and comparing them with the expected returns if no announcement had been made. The deduction is that differences between achieved and expected values reflect the stock market reaction to the news. 
Any such difference is described in previous empirical work as the excess returns from new information, and generally, excess returns are computed for specific event date windows (Fama, 1965; Fama et al., 1969). An assumption that the stock market is informationally efficient (at least in the semi-strong form) would imply that the market reflects all available information in current (pre-announcement) prices prior to the release of the new information of interest (Fama, 1970; Fama \& Miller, 1972; Fama, 1972; Tucker, 1994). Also, it follows that excess returns encountered in the post-event window would be attributable to the new information.

Advances in information technology facilitate the investors' search for investments' information. Investors use Google searches (Drake et al., 2012), Twitter (Blankespoor et al., 2013), EDGAR (Drake et al., 2015), Wikipedia (Xu \& Zhang, 2013), and financial blogs (Saxton \& Anker, 2013) to obtain information for investment decisions (Pennington and Kelton 2016). Implications of accelerated advancement in social media include economic, regulatory, social, and cultural pressures that may affect the utilization of accounting information (Albu \& Klimczak, 2017). The social media becomes another source of accounting information for all stakeholders.

The rational behavior of investors concerning decisions under uncertainty influenced by the perceived personal benefits generated by a decision. The Theory of Expected Utility (Von Neumann \& Morgenstern, 1945) is related to the expected value determined by the expected utility function of different investments. According to the Pecking Order Theory, the managerial decisions to obtain financing are associated with a hierarchy of preferences (Myers \& Majluf, 1984). The lack of symmetric information allows developing a hierarchical order of external financing costs (Tong \& Green, 2005). The asymmetric information and risk aversion of the manager are crucial factors in establishing an order of priorities (Vargas \& Corredor, 2011).

Firm mandatory disclosures are not used by all investors; this may increase the information asymmetry among investors. This situation is applicable to firms that do not highly use traditional intermediaries. Therefore, the firms' use of social media such as Twitter may reduce information asymmetry (Blankespoor et al., 2013). In general, social media use is widespread and used to communicate and retrieve information (Wong, 2017). But, more research is needed to verify how companies manage social media risk (Demek et al., 2018).

The behavior accounting and finance studies the influence of psychology on the decisions made by managers and investors including the possible effect on the markets. As an interdisciplinary approach, it integrates psychological and sociological aspects to finance and accounting implications of other business activities (Ricciardi \& Simon, 2000; Ashta \& Otto, 2011; Kaur et al., 2016). Behavioral finance seeks to explain and improve the knowledge about the emotional 
factors and psychological processes of managers and investors in their decisions (Ricciardi \& Simon, 2000). Because the lack of evidence in classical finance to support decision making, behavioral finance studies try to fill this gap (Kahneman, 2011; Thaler, 1994; Statman, 2014).

Because of the application of psychological concepts to accounting and finance, some emotional biases with respect to financial decision making should be considered. The theory of perspectives introduces differences in dimension when considering a loss or gain. This perspective assumes that a value function is concave for profits, convex for losses, and more pronounced for losses than for profits and assumes a non-linear relationship (Köbberling \& Wakker, 2005; Tversky \& Kahneman, 1991, 1992, 2016; Olsen, 2008).

The abundance of data available through the internet and particularly, social media, makes more challenges to accounting, finance, and management information system classical and behavioral theoretical assumptions. One of the non-traditional sources of information is online social media. The content newness in the social media is becoming useful for many stakeholders and especially in business. Social media is becoming a source of unstructured data that is easily obtained and analyzed (Saleh \& Roberts, 2017). Gamage (2016) states that data analytics will have an impact on the future role of accounting professionals. The social media is not risk-free, there is an inherent risk in sharing accounting information in real time. Errors in accounting information can occur in mandatory and voluntary disclosures, but management can use Twitter to communicate with stakeholders and alleviate the issue (Malhotra \& Malhotra, 2016).

As Twitter is a real-time tool that increases the availability of information, academics and professionals are becoming motivated to consider the online social media content in their decisions. A promising application of Tweets content is the analysis of sentiments that deals with determining the sentiment orientation (Vaitheeswaran \& Arockiam, 2016). This can be realized using predictive analytics that supports the extraction of information from large data (Shmueli \& Koppius, 2011). Also, the integration of the information derived from online social networks and financial markets, enable to extend accounting and finance research to the large-scale analysis of investors' behavior (Souza et al., 2015).

Text mining and online text content such as Tweets enable researchers to extract opinions and sentiments to create beneficial information. Business analysis depends mainly on structured data sources. However, text mining permits management accountants to excerpt decision-related information from unstructured data from different sources such as social media (Appelbaum et al., 2017; Corea, 2016; Alexander \& Gentry, 2014). 


\section{Methodology}

In this article, the market reaction to the President's Tweets is measured using a conventional event study methodology (Brown \& Warner, 1980; 1985). This is by computing returns of major indexes in the U.S.A. and of companies targeted in the President's Tweets. The deduction is that differences between achieved and expected values reflect the reaction to the Tweets. Any such difference is described as the excess returns from new information, and generally, excess returns are computed for specific event date windows (Fama et al., 1969). An assumption that the stock market is informationally efficient, at least in the semi-strong form, would imply that the market reflects all available information in current, pre-Tweets, prices prior to the release of the new information of interest (Fama, 1970; Tucker, 1994). Also, it follows that excess returns encountered in the post-event window would be attributable to the new information.

In the case of the President's Tweets, the precise newness of the information is less easily determined than for other more tightly controlled price sensitive information released by companies. Tweets may be a matter of record with some or all the information already known to the market and included in financial indexes in the pre-announced window. For this reason, event windows include periods prior the event as well as after the event to encompass ambiguity over when the market had access to the information.

In making the event intervals, we also need to minimize the possibility that changes in the companies' stock prices are affected by the release of other new information during the event window. For recognized price sensitive information, for example, new accounting results or acquisitions information release is strictly controlled and hence observations contaminated by such events can be dropped. However, the President's Tweets generally involve more varied types and amounts of new information, and there is no systematic way of unambiguously avoiding confounding events. Inspection of event windows for return spikes associated with other new information such as alliances, product market developments or relevant economic information should be used as a further filter. Despite the precautions, noise is unavoidable. Given the unstructured nature of Tweets, the scope for confounding events and uncertainty about the precise timing of information release, it will be difficult to determine the relationship between the companies' financial performance and the President's Tweets. The main hypotheses of this study are that:

1. The President's Tweets are a material price factor in the companies' financial performance. Therefore,

$\mathrm{H}_{0}$ : The average of excess returns of companies $\left(\mathrm{AERt}_{0}\right)$ mentioned in the President's Tweets equals to zero

$\mathrm{H}_{\mathrm{A}}: \mathrm{AERt}_{0} \# 0$ 
2. The President's Tweets about specific companies are a material price factor. Therefore,

$\mathrm{H}_{0}$ : The excess returns of a company $\left(\mathrm{ERt}_{0}\right)$ mentioned in the President's Tweets equal to zero

$\mathrm{H}_{\mathrm{A}}: \mathrm{ERt}_{0} \# 0$

\subsection{Data collection}

The sample consists of the U.S. President's Tweets from the beginning of 2016 when he dominated the GOP field in August $2017^{3}$. The Tweets were extracted from Donald Trump's Official Twitter Account. We found about 5,700 Tweets, from which 414 Tweets are related to the economy or finance terms. These are used to verify the relationship between the Tweets and the share prices of targeted companies. Also, we encountered 58 Tweets related to 23 public companies. The financial variables related to these companies are obtained from Mergent, Bloomberg Finance, web pages of the companies and Reuters Finance for news. The sample composition with respect to main subjects of the Tweets is given in Table 1.

Table 1: the composition of the sample

\begin{tabular}{lcc}
\hline Content of Tweets & Number & Percentage of sample \\
\hline Economy & 30 & $6 \%$ \\
Finance & 42 & $9 \%$ \\
Tax Reform & 62 & $13 \%$ \\
Immigration & 116 & $25 \%$ \\
Employment & 164 & $35 \%$ \\
Specific companies & 58 & $12 \%$ \\
Total sample & 472 & $100 \%$ \\
\hline
\end{tabular}

Both single Tweets and repeated ones were considered in this study as independent events in computing event returns for the Tweets. The estimation window for the event study was 450 working days [t-452 to t-3], and we consider two days before the event and two days after the event.

\subsection{Data analysis}

The analysis considered the names of companies included in the Tweets, to verify if the Tweets have effects on the performance of these companies. The null hypothesis $\left(\mathrm{H}_{0}\right)$ to be tested is that the mean day ' $\mathrm{t}_{0}$ ' excess return (ER) is equal to zero against the alternative hypothesis $\left(\mathrm{H}_{1}\right)$, that it is significantly different from zero. The

\footnotetext{
${ }^{3}$ http://www.cnn.com/2016/01/26/politics/donald-trump-ted-cruz-polling/index.html (retrieved on 9/29/2017)
} 
estimated average and standard deviation used in the t-test are calculated using the estimation window. For testing the excess return over an interval of length T-days, the test statistic is the ratio of the cumulative mean excess return to its estimated standard deviation (Brown and Warner 1985; MacKinlay 1997).

$$
\sum_{t=1}^{T} M E R_{t} /\left(\sum_{t=1}^{T} S_{M E R_{t}}^{2}\right)^{0.5}
$$

The variance of $\left(\mathrm{MER}_{\mathrm{t}}\right)$ for all cumulative intervals is taken from the estimation period and is adjusted for different evaluation windows as follows: $\sum_{t=1}^{T} M E R_{t} /$ $(\sqrt{T} * \mathrm{~S})$. The null hypothesis $\left(\mathrm{H}_{0}\right)$ is that the excess return (ER) will be jointly normally distributed with a zero-conditional mean and conditional variance $S_{E R_{i t}}^{2}$ where $\left.S_{E R_{i t}}^{2}=S_{j}^{2}+(1 / T)\left[1+\left(R_{m t}-\overline{R_{m t}}\right)\right)^{2} / S_{m}^{2}\right]$. This equation depends on the estimation interval length ' $\mathrm{T}$ '. Where ' $\mathrm{T}$ ' is large enough the second term (the correction term) tends to zero (Patell, 1976; Myer, 1986, 45), and therefore, is ignored in this study. The requirement that returns are jointly normal and temporally independently and identically distributed (Brown and Warner 1985) appeared to be satisfied by the data.

Consistent with event studies in similar research, the market risk-adjusted return (MRAR) is used as follows: $\operatorname{MRA}\left(E R_{j t}\right)=R_{j t}-\beta_{j} * R_{m t}, \beta_{j}$ is the volatility or systematic risk for the security $\left(\beta_{j}=\operatorname{Cov}\left(R_{j}, R_{m}\right) / S_{m}^{2}\right)$. Several event windows are considered around the event day $\left(\mathrm{t}_{0}\right)$ the day of the President's Tweets or the next market day. Also, the CERs are explained using multiple regression as follows: CER $=\alpha_{0}+\sum \alpha_{\mathrm{i}} X_{\mathrm{i}}$, where $\mathrm{X}_{\mathrm{i}}$ 's are the independent variables: natural logarithms of market capitalization, the President's sentiment index in the Tweets, companies' performance measured by average return in the estimation period and companyspecific risk measured by standard deviation in the estimation period, standardized replies to the Tweets measured by number of replies for each Tweets divided by the average of replies in the sample and PPI.

\section{Data interpretation and results}

For the first stage of the research, we completed a macro analysis that takes into consideration major financial market indexes in the U.S.A. in relation to the President's Tweets. There is no significance $(\alpha=5 \%)$ with respect to the arithmetic indexes' returns around the day of the President's Tweets $\left(\mathrm{t}_{0}\right)$. This is an indication that the President's Tweets have no effects on the U.S. financial indexes, at least on the daily indexes prices.

For the second stage of the research, we consider the effect of the Tweets on companies' share prices. Table 2 shows descriptive statistics of the sample companies. The average beta for the sample is 1.09 . The systematic risk, therefore, 
is approximate to the market. The average of companies' market capitalization is 146 billion; this is an indication of the size of the companies in the market. On average, the sample companies showed a negative small return in the estimation period and positive and small return at $\mathrm{t}_{0}$.

As expected, the uncertainty about when exactly the content of the Tweets became public and the variable importance of other news concerning to other new information in the market gives rise to limited significance in the results. The mean excess return for individual companies is generally positive on the day of the announcement $\left(\mathrm{t}_{0}\right)$, but it is not generally significant at the 5\% level. Occasional intervals around the event day show marginal significance at the $10 \%$ level. Four windows were explored, and cumulative excess return (CER) for each window was calculated using MRAR model (see Table 3). The sentiment analysis is used to determine the sign of the Tweets as positive and negative. The relationship between the President's Tweets sentiment signs and excess returns signs for the significant event $(\alpha=10 \%)$ is very low $(\mathrm{r}=8 \%)$ for the event day $\left(\mathrm{t}_{0}\right)$. Appendix $\mathrm{C}$ describes the total sample CER and corresponding significances.

Table 2: Descriptive statistics of selected financial variables of companies that were indicated in the President's Tweets

\begin{tabular}{lcccc}
\hline Variable & Minimum & Maximum & Mean & Std. Deviation \\
\hline Beta & 0.050 & 1.930 & 1.093 & 0.415 \\
M Cap & 927 & 777,770 & 146,436 & 172,007 \\
LnMC & 6.832 & 13.564 & 11.135 & 1.455 \\
Sentiment & -0.997 & 0.994 & 0.252 & 0.710 \\
ComPerf & -0.057 & 0.002 & -0.001 & 0.008 \\
ComStd & 0.011 & 1.965 & 0.052 & 0.265 \\
$\mathrm{Ar}_{\mathrm{t}-2}$ & -0.031 & 0.021 & -0.003 & 0.011 \\
$\mathrm{AR}_{\mathrm{t}-1}$ & -0.031 & 0.043 & 0.002 & 0.013 \\
$\mathrm{AR}_{\mathrm{t} 0}$ & -0.075 & 0.064 & 0.003 & 0.021 \\
$\mathrm{AR}_{\mathrm{t} 1}$ & -0.036 & 0.096 & 0.004 & 0.020 \\
$\mathrm{AR}_{\mathrm{t} 2}$ & -0.044 & 0.023 & -0.003 & 0.012 \\
No $_{\mathrm{i}}$ of & 54 & & &
\end{tabular}

No. of Tweets: $\quad 54$

Variables: Const is the constant in the estimated model $\left(\alpha_{0}\right)$, ComPerf is the company's performance measured as the expected returns of companies in the estimation window, MCap is the market capitalization of millions U.S. dollars used as a proxy for companies' size, Stlike is the standardized number of likes in the President's Tweets (PT) (number of the likes in PT over its average), StRet is the standardized number of retweets in PT (number of the retweets in PT over its average), StRep is the standardized number of replies in PT (number of the replies in PT over its average). The sentiment is the codification by examining the sentiment in the President's Tweets.

ComStd is a company's standard deviation in the estimation window and is considered as a specific company risk indicator; Beta is a proxy for the systematic risk of a company, $\left(\beta_{j}=\right.$ $\left.\operatorname{Cov}\left(R_{j}, R_{m}\right) / S_{m}^{2}\right)$, PPI is an indicator for the Tweets timing, -1 for after the inauguration, 0 for after the election day and before the inauguration, and 1 before the election day. 
Using social media analytics: The effect of President Trump's tweets on companies' performance

Table 3: Summary of the significant CERs in selected event windows

\begin{tabular}{ccccccccc}
\hline $\begin{array}{c}\text { Event } \\
\text { window }\end{array}$ & \multicolumn{2}{c}{$\begin{array}{c}\text { No. } \\
\text { Sentiment } \\
\text { signs }\end{array}$} & $\begin{array}{c}\text { No. of events } \\
\text { with significant } \\
\text { CERs }\end{array}$ & $\begin{array}{c}\text { No. of positive } \\
\text { significant } \\
\text { CERs }\end{array}$ & $\begin{array}{c}\text { No. of negative } \\
\text { significant } \\
\text { CERs }\end{array}$ \\
\hline & $\mathrm{P}$ & $\mathrm{N}$ & $\alpha=10 \%$ & $\alpha=5 \%$ & $\alpha=10 \%$ & $\alpha=5 \%$ & $\alpha=10 \%$ & $\alpha=5 \%$ \\
\hline$[-2,-1]$ & 0 & 1 & 1 & 0 & 0 & 0 & 1 & 0 \\
0 & 12 & 6 & 18 & 8 & 12 & 7 & 6 & 1 \\
{$[1,2]$} & 4 & 1 & 5 & 3 & 3 & 2 & 2 & 1 \\
{$[-2,2]$} & 1 & 1 & 2 & 0 & 1 & 0 & 1 & 0 \\
\hline
\end{tabular}

Table 4 shows the Person correlation between the variables that are used in the multiple regression. The correlation results assist in the selection of the explaining variables in the multiple regression. The multiple regression is used to explore the relationship between cumulative excess return (CER) and a company's size, performance, systematic risk, specific risks, and to differentiate between the Tweets periods before the election, after the election and before the inauguration and after the inauguration date of the president.

Table 4: Pearson correlation for selected variables

\begin{tabular}{|c|c|c|c|c|c|c|c|c|}
\hline & 1 & 2 & 3 & 4 & 5 & 6 & 7 & 8 \\
\hline Market Cap & 1.000 & & & & & & & \\
\hline Sentiment & $\begin{array}{c}0.072 \\
(0.302)\end{array}$ & 1.000 & & & & & & \\
\hline ComPerf & $\begin{array}{c}0.211 \\
(0.063)\end{array}$ & $\begin{array}{l}-0.140 \\
(0.157)\end{array}$ & 1.000 & & & & & \\
\hline ComStd & $\begin{array}{l}-0.200 \\
(0.073)\end{array}$ & $\begin{array}{c}0.137 \\
(0.161)\end{array}$ & $\begin{array}{l}-.998 * * \\
(0.000)\end{array}$ & 1.000 & & & & \\
\hline StRep & $\begin{array}{l}-0.125 \\
(0.184)\end{array}$ & $\begin{array}{l}-0.211 \\
(0.063)\end{array}$ & $\begin{array}{c}0.018 \\
(0.448)\end{array}$ & $\begin{array}{l}-0.023 \\
(0.435)\end{array}$ & 1.000 & & & \\
\hline StRet & $\begin{array}{c}0.146 \\
(0.145)\end{array}$ & $\begin{array}{c}0.168 \\
(0.112)\end{array}$ & $\begin{array}{l}-0.100 \\
(0.236)\end{array}$ & $\begin{array}{c}0.110 \\
(0.215)\end{array}$ & $\begin{array}{c}0.171 \\
(0.108)\end{array}$ & 1.000 & & \\
\hline Stlike & $\begin{array}{c}0.090 \\
(0.259)\end{array}$ & $\begin{array}{c}0.448^{* *} \\
(0.000)\end{array}$ & $\begin{array}{l}-0.150 \\
(0.140)\end{array}$ & $\begin{array}{c}0.151 \\
(0.139)\end{array}$ & $\begin{array}{l}0.249^{*} \\
(0.034)\end{array}$ & $\begin{array}{c}0.837 * * \\
(0.000)\end{array}$ & 1.000 & \\
\hline PPI & $\begin{array}{l}-0.191 \\
(0.084)\end{array}$ & $\begin{array}{c}0.556^{* * *} \\
(0.000)\end{array}$ & $\begin{array}{l}-0.151 \\
(0.138)\end{array}$ & $\begin{array}{c}0.150 \\
(0.140)\end{array}$ & $\begin{array}{c}0.121 \\
(0.191)\end{array}$ & $\begin{array}{c}0.076 \\
(0.292)\end{array}$ & $\begin{array}{c}0.446^{* * *} \\
(0.000)\end{array}$ & 1.000 \\
\hline $\mathrm{AR}_{\mathrm{t} 0}$ & $\begin{array}{l}-0.106 \\
(0.223)\end{array}$ & $\begin{array}{l}-0.016 \\
(0.455)\end{array}$ & $\begin{array}{c}0.504^{* *} \\
(0.000)\end{array}$ & $\begin{array}{c}-0.504 * * \\
(0.000)\end{array}$ & $\begin{array}{c}0.186 \\
(0.089)\end{array}$ & $\begin{array}{l}-0.034 \\
(0.403)\end{array}$ & $\begin{array}{c}0.029 \\
(0.417)\end{array}$ & $\begin{array}{l}-0.093 \\
(0.251)\end{array}$ \\
\hline
\end{tabular}

The results of the multiple regression in Model \#8 suggest that the two main variables, namely, companies' performance measured by the average of returns in the event window and companies' size proxied by market capitalization, contributed most to the explanation (see Table 5). Therefore, the sentiment of the President's Tweets' content, number of likes, number of reply and number of retweets do not 
add an explanation to the original model that include the main variables. This is consistent with the assumptions of the semi-strong market efficiency hypothesis (Fama 1970). Possible explanations for this are that the market already reflects all information of the content of the Tweets or do not consider them as relevant.

Table 5: Regression Summary

\begin{tabular}{|c|c|c|c|c|c|c|c|c|}
\hline \multirow[b]{2}{*}{ Varaibles } & \multicolumn{8}{|c|}{ Models } \\
\hline & 8 & 7 & 6 & 5 & 4 & 3 & 2 & 1 \\
\hline Const & $\sqrt{ }$ & $\sqrt{ }$ & $\sqrt{ }$ & $\sqrt{ }$ & $\sqrt{ }$ & $\sqrt{ }$ & $\sqrt{ }$ & $\sqrt{ }$ \\
\hline ComPerf & $\sqrt{ }$ & $\sqrt{ }$ & $\sqrt{ }$ & $\sqrt{ }$ & $\sqrt{ }$ & $\sqrt{ }$ & $\sqrt{ }$ & $\sqrt{ }$ \\
\hline MCap & $\sqrt{ }$ & $\sqrt{ }$ & $\sqrt{ }$ & $\sqrt{ }$ & $\sqrt{ }$ & $\sqrt{ }$ & $\sqrt{ }$ & $\sqrt{ }$ \\
\hline Stlike & & $\sqrt{ }$ & $\sqrt{ }$ & $\sqrt{ }$ & $\sqrt{ }$ & $\sqrt{ }$ & $\sqrt{ }$ & $\sqrt{ }$ \\
\hline PPI & & & $\sqrt{ }$ & $\sqrt{ }$ & $\sqrt{ }$ & $\sqrt{ }$ & $\sqrt{ }$ & $\sqrt{ }$ \\
\hline StRet & & & & $\sqrt{ }$ & $\sqrt{ }$ & $\sqrt{ }$ & $\sqrt{ }$ & $\sqrt{ }$ \\
\hline StRep & & & & & $\sqrt{ }$ & $\sqrt{ }$ & $\sqrt{ }$ & $\sqrt{ }$ \\
\hline Sentiment & & & & & & $\sqrt{ }$ & $\sqrt{ }$ & $\sqrt{ }$ \\
\hline ComStd & & & & & & & $\sqrt{ }$ & $\sqrt{ }$ \\
\hline Beta & & & & & & & & $\sqrt{ }$ \\
\hline $\mathrm{R}$ & 0.57 & 0.58 & 0.59 & 0.61 & 0.62 & 0.63 & 0.64 & 0.64 \\
\hline $\mathrm{R}^{2}$ & 0.32 & 0.33 & 0.35 & 0.37 & 0.39 & 0.40 & 0.41 & 0.41 \\
\hline $\operatorname{Adj} R^{2}$ & 0.30 & 0.29 & 0.29 & 0.31 & 0.31 & 0.31 & 0.30 & 0.29 \\
\hline F-test & 12.32 & 8.26 & 6.49 & 5.71 & 4.97 & 4.36 & 3.84 & 3.37 \\
\hline Sig. & 0.00 & 0.00 & 0.00 & 0.00 & 0.00 & 0.00 & 0.00 & 0.00 \\
\hline
\end{tabular}

\section{Conclusions}

The social media has been increasingly used in financial performance reporting; this generates opportunities and challenges for companies and stakeholders. Microblogging is becoming an important source of unstructured data available for analysis for many stakeholders in the business. It is argued that President Trump's Tweets have become a source of influence in the stock market of the U.S.A. and other international markets. Many also argue the President can highly impact the companies he mentions or targets in his Tweets. The objective of this study is to explore if there is a relationship between the U. S. President's Tweets and the companies' financial performance.

The main results of the study show that there are no significant effects of such Tweets on the stock market. Also, on average, there are no significant changes in companies' 
share prices on the day of the Tweets. This is an indication that either the Tweets may only influence the companies share prices in a spontaneous moment or the information contained in the President's Tweets is already reflected in the share prices before the day of the Tweets. This is consistent with the efficient market assumptions.

The number of Tweets is not large enough to divide the sample into subgroups to reflect contextual factors such as industrial classification, companies' performance, size, or macroeconomic factors. Factors of potential interest cannot be realistically pursued with the small amount of relatively noisy data included in the Tweets. However, the work in this article can be justified in that it provides some worthwhile suggestions for future study and secondly that although it may not reflect the value relevance of Tweets' characteristics at normal levels of significance, it contributes to the use of non-financial factors as important factors in companies' valuation. This research also contributes to the existing stream of research in the area of social media and its implications for accounting and information systems practices.

For future research, we suggest that it is important to use a larger sample as more Tweets of the President become available, to do more robust analysis by clustering companies regarding their relationship to the Federal Government and by considering the trading transactions within the same day of the Tweets. According to Souza and Aste $(2015 ; 2016)$, online social media and stock markets have a nonlinear causal relationship. Therefore, another avenue of research can be explored when the data becomes large. Also, it is worthwhile to further investigate this relationship by taking the spontaneous effect of the Tweets on the companies' shares prices into account.

\section{References}

Albu, C. N., \& Klimczak, K. M. (2017) "Small and Medium-sized Entities Reporting in Central and Eastern Europe", Journal of Accounting and Management Information Systems, 16(2): 221-228.

Alexander, R. M., \& Gentry, J. K. (2014) "Using social media to report financial results", Business Horizons, 57(2): 161-167.

Alles, M., \& Gray, G. L. (2016) "Incorporating big data in audits: Identifying inhibitors and a research agenda to address those inhibitors", International Journal of Accounting Information Systems, 22: 44-59.

Appelbaum, D., Kogan, A., Vasarhelyi, M., \& Yan, Z. (2017) "Impact of business analytics and enterprise systems on managerial accounting", International Journal of Accounting Information Systems, 25:29-44.

Ashta, A., \& Otto, P. E. (2011) "Project valuation in the presence of loss aversion during economic crises", Strategic Change, 20(5-6): 171-186. 
Asquith, P., \& Weiss, L. A. (2016) Lessons in corporate finance: A case studies approach to financial tools, financial policies, and valuation, John Wiley \& Sons.

Blankespoor, E., Miller, G. S., \& White, H. D. (2013) "The role of dissemination in market liquidity: Evidence from firms' use of Twitter"T", The Accounting Review, 89(1): 79-112.

Bollen, J., Mao, H., \& Zeng, X. (2011) "Twitter mood predicts the stock market", Journal of Computational Science, 2(1): 1-8.

Brown, S. J., \& Warner, J. B. (1980) "Measuring security price performance", Journal of Financial Economics, 8(3): 205-258.

Brown, S. J., \& Warner, J. B. (1985) "Using daily stock returns: The case of event studies", Journal of Financial Economics, 14(1): 3-31.

Corea, F. (2016) "Can Twitter Proxy the Investors' Sentiment? The Case for the Technology Sector", Big Data Research, 4: 70-74.

Demek, K. C., Raschke, R. L., Janvrin, D. J., \& Dilla, W. N. (2018) "Do organizations use a formalized risk management process to address social media risk?", International Journal of Accounting Information Systems, 28: 31-44.

Drake, M. S., Roulstone, D. T., \& Thornock, J. R. (2012) "Investor information demand: Evidence from Google searches around earnings announcements", Journal of Accounting Research, 50(4): 1001-1040.

Drake, M. S., Roulstone, D. T., \& Thornock, J. R. (2015) "The determinants and consequences of information acquisition via EDGAR", Contemporary Accounting Research, 32(3): 1128-1161.

Economist. (2016) "The Economic Consequences of Donald Trump", Retrieved on $10 / 01 / 2017$, from https://www.economist.com/blogs/freeexchange/2016/11/global-economy

EY. (2014) "Improving Disclosure Effectiveness", Retrieved on 10/01/2017 from http://www.ey.com/Publication/vwLUAssets/Applying_IFRS:_Improving_ disclosure_effectiveness/\$FILE/Applying-DisclEffectivenessJuly\%202014.pdf

Fama, E. F. (1965) "The behavior of stock-market prices", The Journal of Business, 38(1): 34-105.

Fama, E. F. (1970) "Efficient capital markets: A review of theory and empirical work", The Journal of Finance, 25(2): 383-417.

Fama, E. F. (1972) "Components of investment performance", The Journal of Finance, 27(3): 551-567.

Fama, E. F., Fisher, L., Jensen, M. C., \& Roll, R. (1969) "The adjustment of stock prices to new information", International Economic Review, 10(1): 1-21. 
Fama, E. F., \& Miller, M. H. (1972) The Theory of Finance, Holt Rinehart \& Winston.

Francis, N., Owyang, M., \& Soques, D. (2015) "Does the United States lead foreign business cycles?", Retrived on 10/01/2017, from https://files.stlouisfed.org/files/htdocs/publications/review/2015/q2/Francis OwyangSoques.pdf

Gabrovšek, P., Aleksovski, D., Mozetič, I., \& Grčar, M. (2017) "Twitter sentiment around the Earnings Announcement events", PloS one, 12(2), e0173151.

Gamage, P. (2016) "Big Data: are accounting educators ready?", Accounting \& Management Information Systems/Contabilitate şi Informatica de Gestiune, 15(3): 588-604.

Jensen, M. C. (1969) "Risk, the pricing of capital assets, and the evaluation of investment portfolios", The Journal of Business, 42(2): 167-247.

Kahneman, D. (2011) Thinking, fast and slow, Macmillan.

Kaur, P., Virani, S., \& Fazalbhoy, S. (2016) "Psychologicak Traits and Demographic Factors do They Affect Investor's Behavior?", Indian Journal of Management Science, 6(1): 46.

Kendall, M. G., \& Hill, A. B. (1953) "The analysis of economic time-series-part i: Prices", Journal of the Royal Statistical Society. Series A (General), 116(1): $11-34$.

Kim, S.-K. (2015) "Challeges in the management of data in the" Big Data" age", International Journal of Business Research and Information Technology, 2(1): 1-14.

Kose, M. A., Lakatos, C., Ohnsorge, F., \& Stocker, M. (2017) "The global role of the US economy: Linkages, policies and spillovers", papers.ssrn.com.

Köbberling, V., \& Wakker, P. P. (2005) "An index of loss aversion", Journal of Economic Theory, 122(1): 119-131.

Lintner, J. (1965) "Security prices, risk, and maximal gains from diversification", The Journal of Finance, 20(4): 587-615.

MacKinlay, A. C. (1997) "Event studies in economics and finance", Journal of Economic Literature, 35(1): 13-39.

Malhotra, C. K., \& Malhotra, A. (2016) "How CEOs can leverage twitter", MIT Sloan Management Review, 57(2): 73.

Markowitz, H. (1952) "Portfolio selection", The Journal of Finance, 7(1): 77-91.

Markowitz, H., \& Selection, P. (1959) "Efficient diversification of investments", John Wiley and Sons, 12: 26-31.

Modigliani, F. (1961) "Long-run implications of alternative fiscal policies and the burden of the national debt", The Economic Journal, 71(284): 730-755.

Modigliani, F., \& Miller, M. H. (1958) "The cost of capital, corporation finance and the theory of investment", The American Economic Review, 48(3): 261-297. 
Mossin, J. (1966) "Equilibrium in a capital asset market", Econometrica: Journal of the Econometric Society, 34: 768-783.

Myers, R. (1986) Classical and modern regression with applications, Duxbury Press, Boston.

Myers, S. C., \& Majluf, N. S. (1984) "Corporate financing and investment decisions when firms have information that investors do not have", Journal of Financial Economics, 13(2): 187-221.

O'Reilly, C. A. (1982) "Variations in decision makers' use of information sources: The impact of quality and accessibility of information", Academy of Management Journal, 25(4): 756-771.

Olsen, R. A. (2008) "Perceptions of financial risk: axioms and affect", The Icfai University Journal of Behavioral Finance, 5(4): 58-80.

Patell, J. M. (1976) "Corporate forecasts of earnings per share and stock price behavior: Empirical test", Journal of Accounting Research, 14(2): 246-276.

Pennington, R. R., \& Kelton, A. S. (2016) "How much is enough? An investigation of nonprofessional investors information search and stopping rule use", International Journal of Accounting Information Systems, 21: 47-62.

Ricciardi, V., \& Simon, H. K. (2000) "What is behavioral finance?", papers.ssrn.com.

Saleh, A., \& Roberts, C. (2017) "The impact of online corporate reporting quality on analyst following and properties of their EPS forecasts", Journal of Accounting and Management Information Systems, 16(1): 59-88.

Saxton, G. D., \& Anker, A. E. (2013) "The aggregate effects of decentralized knowledge production: Financial bloggers and information asymmetries in the stock market", Journal of Communication, 63(6): 1054-1069.

Schumaker, R. P., \& Chen, H. (2009a) "A quantitative stock prediction system based on financial news", Information Processing \& Management, 45(5): 571-583.

Schumaker, R. P., \& Chen, H. (2009b), "Textual analysis of stock market prediction using breaking financial news: The AZFin text system", ACM Transactions on Information Systems (TOIS), 27(2): 12.

Sharpe, W. F. (1964) "Capital asset prices: A theory of market equilibrium under conditions of risk", The Journal of Finance, 19(3): 425-442.

Shmueli, G., \& Koppius, O. R. (2011) "Predictive analytics in information systems research", MIS Quarterly, Sep: 553-572.

Souza, T. T., \& Aste, T. (2016) "A nonlinear impact: evidences of causal effects of social media on market prices", arXiv preprint arXiv:1601.04535.

Souza, T. T. P., Kolchyna, O., Treleaven, P. C., \& Aste, T. (2015) "Twitter sentiment analysis applied to finance: A case study in the retail industry", arXiv preprint arXiv:1507.00784.

Statman, M. (2014) "Behavioral finance: Finance with normal people", Borsa Istanbul Review, 14(2): 65-73. 
Stewart, E. (2017) "Trump's tweets don't have much effect on the stock market", Retrieved on 10/01/2017 from https://www.thestreet.com/story/13997431/1/trump-s-tweets-don-t-havemuch-effect-on-stock-market.html

Tafti, A., Zotti, R., \& Jank, W. (2016) "Real-time diffusion of information on Twitter and the financial markets", PloS one, 11(8), e0159226.

Thaler, R. H. (1994) Quasi rational economics, Russell Sage Foundation.

Tobin, J. (1958) "Liquidity preference as behavior towards risk", The Review of Economic Studies, 25(2): 65-86.

Tong, G., \& Green, C. J. (2005) "Pecking order or trade-off hypothesis? Evidence on the capital structure of Chinese companies", Applied Economics, 37(19): 2179-2189.

Tucker, A. L. (1994) "Contemporary portfolio theory and risk management", West publishing company.

Tversky, A., \& Kahneman, D. (1991) "Loss aversion in riskless choice: A referencedependent model", The Quarterly Journal of Economics, 106(4): 10391061.

Tversky, A., \& Kahneman, D. (1992) "Advances in prospect theory: Cumulative representation of uncertainty", Journal of Risk and uncertainty, 5(4): 297323.

Tversky, A., \& Kahneman, D. (2016) "Advances in prospect theory: cumulative representation of uncertainty", Readings in Formal Epistemology: 493-519, Springer.

Vaitheeswaran, G., \& Arockiam, L. (2016) "Machine Learning Based Approach to Enhance the Accuracy of Sentiment Analysis on Tweets", International Journal of Advance Research in Computer Science and Management Studies, 4(5): 72-82

Vargas, S. M. Z., \& Corredor, G. A. A. (2011) "Estructura de capital. Evolución teórica", Criterio libre, 9(15): 81.

Von Neumann, J., \& Morgenstern, O. (1945) "Theory of games and economic behavior", Bull. Amer. Math. Soc, 51(7): 498-504.

Wong, C. (2017) "How did they make it? An examination of online personal branding: A pitch", Journal of Accounting and Management Information Systems, 16(3): 413-420.

Worrell, J., Wasko, M., \& Johnston, A. (2013) "Social network analysis in accounting information systems research", International Journal of Accounting Information Systems, 14(2): 127-137.

Xu, S. X., \& Zhang, X. (2013) "Impact of Wikipedia on Market Information Environment: Evidence on Management Disclosure and Investor Reaction", MIS Quarterly, 37(4): 1043-1068. 


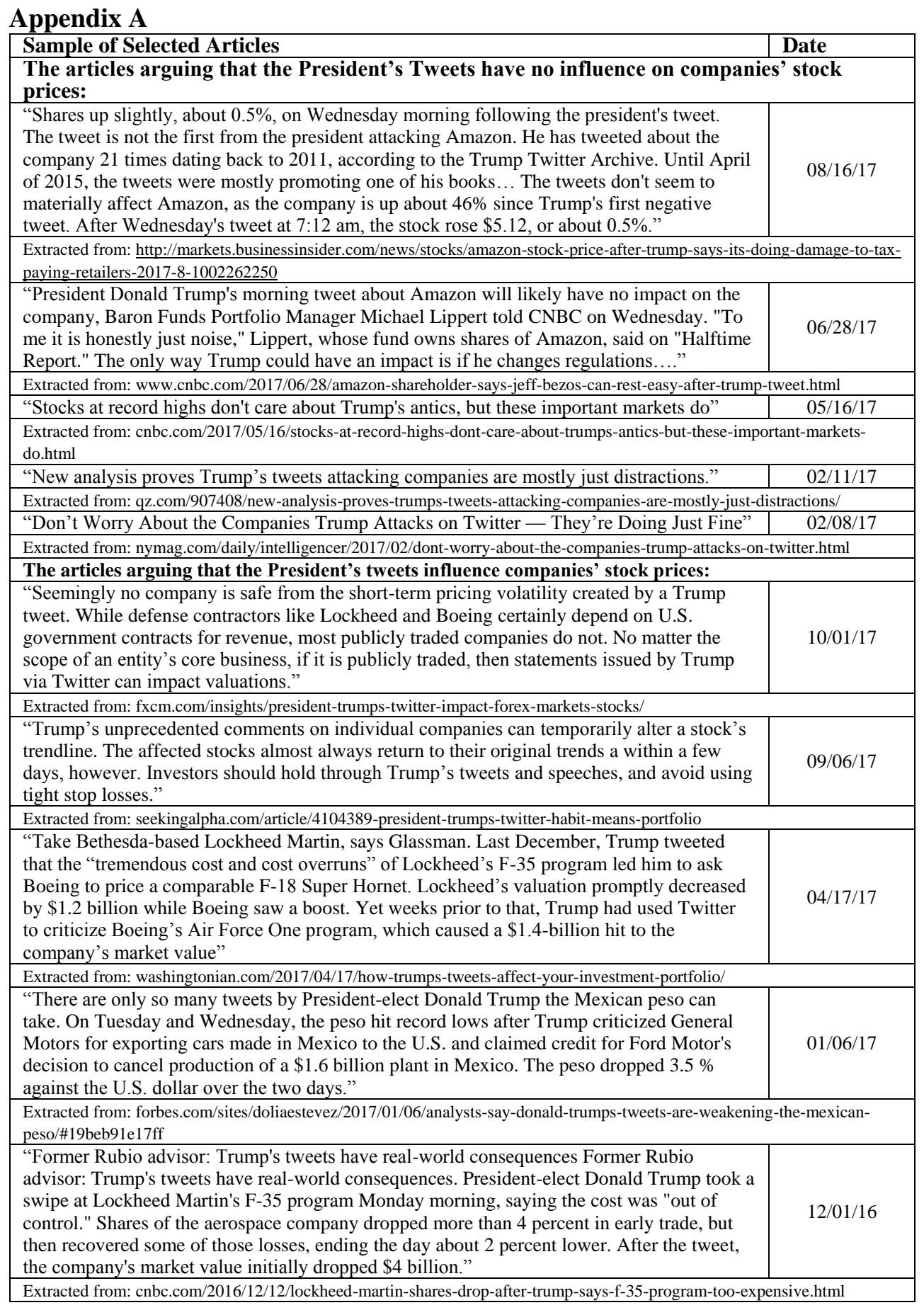


Using social media analytics: The effect

of President Trump's tweets on companies' performance

\begin{tabular}{|c|c|c|c|c|c|c|}
\hline Company & B & M Cap & Sentiment & Keywords & Date & Likes \\
\hline Amazon & 1.38 & 450.88 & -0.53 & damage states cities & $8 / 16 / 170: 05$ & 70560 \\
\hline Apple & 1.43 & 777.77 & -0.25 & terrorist radical such products & $2 / 19 / 1616: 38$ & 10235 \\
\hline Apple & 1.43 & 777.77 & -0.21 & not give terrorists & $2 / 19 / 1613: 32$ & 9204 \\
\hline Boeing & 1.18 & 150.32 & 0.66 & spend order & 2/17/17 6:38 & 98190 \\
\hline Boeing Co & 1.18 & 150.32 & -0.20 & cost out of control & $12 / 22 / 1614: 26$ & 60934 \\
\hline Boeing Co & 1.18 & 150.32 & -0.89 & future control cancel order & 12/6/16 8:52 & 138658 \\
\hline Charter Comm & 1.50 & 105.64 & 0.97 & thank communications years & $3 / 24 / 1712: 59$ & 88508 \\
\hline Exxon & 0.61 & 343.08 & 0.96 & hank more investment construction & 3/6/17 22:50 & 98492 \\
\hline Exxon & 0.61 & 343.08 & 0.77 & jobs, jobs, jobs thank you & $3 / 6 / 1722: 49$ & 86344 \\
\hline Exxon & 0.61 & 343.08 & 0.25 & coast construction & $3 / 6 / 17$ 16:22 & 115651 \\
\hline Exxon & 0.61 & 343.08 & 0.86 & Congratulates Job-Creating Investment & $3 / 6 / 1716: 19$ & 69989 \\
\hline Exxon & 0.61 & 343.08 & 0.97 & great world & $12 / 13 / 163: 43$ & 74977 \\
\hline Exxon & 0.61 & 343.08 & -0.14 & whether I choose him or not for & $12 / 11 / 167: 29$ & 51041 \\
\hline Facebook & 0.54 & 472.86 & -0.25 & dishonest criminal media & $10 / 30 / 169: 26$ & 70517 \\
\hline Facebook & 0.54 & 472.86 & -0.89 & fight fraudulent commercials & 3/6/16 18:58 & 25881 \\
\hline Fiat Chrysler & 1.69 & 26.63 & 0.97 & thank dollar week & 1/9/17 9:16 & 108587 \\
\hline Fiat Chrysler & 1.69 & 26.63 & 0.65 & adding jobs & $1 / 9 / 176: 14$ & 99954 \\
\hline Ford Motor & 1.37 & 47.42 & 0.63 & major investment today & $3 / 28 / 175: 36$ & 108333 \\
\hline Ford Motor & 1.37 & 47.42 & 0.92 & great general fields mark & $1 / 24 / 1716: 46$ & 100200 \\
\hline Ford Motor Co. & 1.37 & 47.42 & 0.97 & thank dollar week & 1/9/17 9:16 & 108587 \\
\hline Ford Motor Co. & 1.37 & 47.42 & 0.99 & more plant beginning thank you to ford & 1/4/17 5:19 & 85763 \\
\hline Ford Motor Co. & 1.37 & 47.42 & 0.69 & Ford to invest & $1 / 3 / 178: 44$ & 52338 \\
\hline Ford Motor Co. & 1.37 & 47.42 & 0.90 & great confidence & 11/17/16 21:15 & 115193 \\
\hline Ford Motor Co. & 1.37 & 47.42 & 0.21 & keep plant & 11/17/16 21:01 & 162618 \\
\hline Ford Motor Co. & 1.37 & 47.42 & -1.00 & weak strong need borders others & $3 / 15 / 1615: 03$ & 15761 \\
\hline Ford Motor Co. & 1.37 & 47.42 & -0.64 & only One Who Understands & $2 / 13 / 1619: 24$ & 4643 \\
\hline Ford Motor Co. & 1.37 & 47.42 & -0.90 & jobs being eliminated & $2 / 13 / 1615: 16$ & 5449 \\
\hline Ford Motor. & 1.37 & 47.42 & -0.25 & totally biased others & 1/18/17 4:34 & 47659 \\
\hline Foxconn & 0.79 & 127.19 & 0.89 & not forget will spending & $8 / 4 / 175: 21$ & 60284 \\
\hline Foxconn & 0.79 & 127.19 & 0.98 & investing potential new jobs & $7 / 26 / 17$ 19:01 & 91369 \\
\hline General Motors & 1.64 & 58.51 & 0.92 & great general fields mark & $1 / 24 / 1716: 46$ & 100200 \\
\hline General Motors & 1.64 & 58.51 & -0.25 & totally biased others & 1/18/17 4:34 & 47659 \\
\hline General Motors & 1.64 & 58.51 & 0.87 & thank you starting big jobs & $1 / 17 / 179: 55$ & 103067 \\
\hline General Motors & 1.64 & 58.51 & -0.25 & make border pay tax & $1 / 3 / 177: 30$ & 72421 \\
\hline Google & 0.95 & 641.82 & -0.25 & dishonest criminal media & $10 / 30 / 169: 26$ & 70517 \\
\hline Griffon & 1.30 & 0.93 & 0.88 & jobs keep wealth & 5/1/17 15:30 & 36970 \\
\hline Harley Davidson & 0.86 & 8.28 & 0.21 & executives remarks & $2 / 3 / 1710: 26$ & 11401 \\
\hline Harley Davidson & 0.86 & 8.28 & 0.88 & great meeting & $2 / 2 / 179: 56$ & 44282 \\
\hline Intel & 1.17 & 174.71 & 0.99 & great investment innovation & $2 / 8 / 1714: 22$ & 96868 \\
\hline Lockheed Martin & 0.59 & 88.49 & -0.25 & totally biased others & 1/18/17 4:34 & 47659 \\
\hline Lockheed Martin & 0.59 & 88.49 & -0.20 & cost out of control & $12 / 22 / 1617: 26$ & 60947 \\
\hline Mazda & 1.93 & 9.10 & 0.98 & great investment & 8/4/17 5:02 & 117708 \\
\hline Nordstrom & 0.72 & 7.87 & -0.68 & terrible daughter person thing & $2 / 8 / 177: 51$ & 141209 \\
\hline Rexnord & 1.65 & 2.58 & -0.84 & move fired employees & 5/7/17 17:58 & 44283 \\
\hline Rexnord & 1.65 & 2.58 & -0.96 & more firing workers country & $12 / 2 / 1622: 06$ & 62716 \\
\hline Toyota & 0.73 & 178.77 & 0.98 & great investment & \begin{tabular}{l|}
$8 / 4 / 175: 02$ \\
\end{tabular} & 117708 \\
\hline Toyota & 0.73 & \begin{tabular}{|l|}
178.77 \\
\end{tabular} & -0.25 & border pay big tax & 1/5/17 13:14 & 106847 \\
\hline TransCanada & 0.67 & 42.55 & 0.98 & approval great day & $3 / 24 / 1712: 03$ & 66052 \\
\hline
\end{tabular}

Vol. 17, No. 1 
Accounting and Management Information Systems

\begin{tabular}{|c|c|c|c|c|c|c|}
\hline Company & B & M Cap & Sentiment & Keywords & Date & Likes \\
\hline TransCanada & 0.67 & 42.55 & 0.65 & extra move signing orders access office & $1 / 24 / 179: 49$ & 130829 \\
\hline Twitter & 1.02 & 12.48 & -0.25 & dishonest criminal media & $10 / 30 / 169: 26$ & 70517 \\
\hline Twitter & 1.02 & 12.48 & -0.89 & fight fraudulent commercials & $3 / 6 / 1618: 58$ & 25881 \\
\hline United Tech & 1.01 & 91.25 & 0.87 & wonderful great carrier working & $12 / 1 / 166: 38$ & 55814 \\
\hline United Tech & 1.01 & 91.25 & 0.81 & great sell many look tomorrow carrier & 11/30/16 19:48 & 65923 \\
\hline United Tech & 1.01 & 91.25 & 0.99 & wonderful great keep carrier thanks & $11 / 29 / 1622: 50$ & 81898 \\
\hline United Tech & 1.01 & 91.25 & 0.76 & great make & 11/29/16 19:40 & 68681 \\
\hline United Tech & 1.01 & 91.25 & 0.70 & know company & 11/24/16 7:11 & 135743 \\
\hline United Tech & 1.01 & 91.25 & -0.64 & only One Who Understands & $2 / 13 / 1611: 24$ & 4643 \\
\hline Walmart & 0.05 & 236.47 & 0.87 & thank you starting big jobs & $1 / 17 / 179: 55$ & 103067 \\
\hline
\end{tabular}


Using social media analytics: The effect

of President Trump's tweets on companies' performance

\section{Appendix C}

\begin{tabular}{|c|c|c|c|c|c|c|c|c|}
\hline Code & Avg AR & Std AR & t-1 & Sig & $t_{0}$ & Sig & $\mathbf{t}_{1}$ & Sig \\
\hline GFF & 0.001 & 0.015 & 0.007 & 0.450 & 0.013 & 0.860 & -0.026 & -1.760 \\
\hline AAPL & 0.001 & 0.014 & -0.011 & -0.810 & 0.001 & 0.040 & -0.015 & -1.100 \\
\hline $\mathrm{BA}$ & 0.001 & 0.011 & 0.010 & 0.890 & 0.010 & 0.970 & 0.010 & 0.920 \\
\hline $\mathrm{BA}$ & 0.001 & 0.011 & 0.001 & 0.060 & 0.003 & 0.270 & 0.010 & 0.930 \\
\hline BA & 0.001 & 0.011 & 0.004 & 0.400 & -0.003 & -0.280 & -0.006 & -0.550 \\
\hline UTX & 0.000 & 0.008 & 0.006 & 0.760 & -0.001 & -0.170 & -0.012 & -1.550 \\
\hline UTX & 0.000 & 0.008 & -0.001 & -0.170 & -0.012 & -1.550 & 0.003 & 0.350 \\
\hline UTX & 0.000 & 0.008 & 0.003 & 0.430 & 0.002 & 0.290 & 0.010 & 1.200 \\
\hline UTX & 0.000 & 0.008 & 0.010 & 1.220 & -0.010 & -1.240 & -0.007 & -0.900 \\
\hline CHTR & 0.001 & 0.017 & -0.006 & -0.370 & 0.007 & 0.410 & 0.007 & 0.420 \\
\hline XOM & 0.000 & 0.010 & 0.007 & 0.730 & -0.015 & -1.480 & -0.002 & -0.150 \\
\hline $\mathrm{XOM}$ & 0.000 & 0.010 & -0.015 & -1.480 & -0.002 & -0.150 & 0.007 & 0.710 \\
\hline XOM & 0.000 & 0.010 & -0.002 & -0.150 & 0.007 & 0.710 & -0.011 & -1.110 \\
\hline XOM & 0.000 & 0.010 & 0.002 & 0.160 & -0.014 & -1.390 & 0.014 & 1.410 \\
\hline XOM & 0.000 & 0.010 & -0.014 & -1.390 & 0.014 & 1.410 & 0.023 & 2.280 \\
\hline XOM & 0.000 & 0.010 & 0.014 & 1.410 & 0.023 & 2.280 & 0.005 & 0.530 \\
\hline Ford & 0.000 & 0.011 & 0.003 & 0.320 & 0.015 & 1.400 & -0.001 & -0.130 \\
\hline Ford & 0.000 & 0.011 & 0.007 & 0.700 & 0.000 & 0.000 & 0.002 & 0.210 \\
\hline Ford & 0.000 & 0.011 & 0.016 & 1.500 & -0.002 & -0.180 & 0.000 & 0.040 \\
\hline Ford & 0.000 & 0.011 & -0.031 & -2.910 & 0.035 & 3.310 & 0.026 & 2.460 \\
\hline Ford & 0.000 & 0.011 & 0.035 & 3.310 & 0.026 & 2.460 & -0.006 & -0.570 \\
\hline Ford & 0.000 & 0.011 & -0.008 & -0.760 & -0.005 & -0.510 & -0.016 & -1.530 \\
\hline Ford & 0.000 & 0.011 & -0.005 & -0.510 & -0.016 & -1.530 & 0.003 & 0.240 \\
\hline Ford & 0.000 & 0.011 & -0.017 & -1.590 & 0.011 & 1.030 & 0.005 & 0.500 \\
\hline Ford & 0.000 & 0.011 & 0.011 & 1.030 & 0.005 & 0.500 & 0.003 & 0.240 \\
\hline Ford & 0.000 & 0.011 & 0.011 & 1.030 & 0.006 & 0.580 & 0.004 & 0.350 \\
\hline$\overline{F B}$ & 0.001 & 0.018 & -0.008 & -0.440 & -0.003 & -0.140 & 0.014 & 0.770 \\
\hline FB & 0.001 & 0.018 & 0.009 & 0.520 & -0.027 & -1.490 & -0.014 & -0.800 \\
\hline FCAU & 0.001 & 0.021 & 0.021 & 1.000 & 0.025 & 1.180 & 0.064 & 3.070 \\
\hline FCAU & 0.001 & 0.021 & 0.025 & 1.180 & 0.064 & 3.070 & 0.013 & 0.640 \\
\hline Foxcon & 0.002 & 0.023 & 0.043 & 1.900 & -0.006 & -0.260 & 0.016 & 0.730 \\
\hline Foxcon & 0.002 & 0.023 & 0.010 & 0.440 & -0.014 & -0.610 & 0.008 & 0.350 \\
\hline GM & 0.000 & 0.014 & -0.016 & -1.190 & 0.022 & 1.580 & -0.002 & -0.150 \\
\hline GM & 0.000 & 0.014 & 0.002 & 0.180 & 0.004 & 0.320 & 0.004 & 0.270 \\
\hline$\overline{G M}$ & 0.000 & 0.014 & 0.004 & 0.320 & 0.004 & 0.270 & -0.008 & -0.580 \\
\hline GM & 0.000 & 0.014 & -0.019 & -1.400 & 0.042 & 3.070 & -0.006 & -0.410 \\
\hline GOOGL & 0.001 & 0.014 & 0.001 & 0.050 & -0.012 & -0.900 & 0.005 & 0.370 \\
\hline HOG & 0.000 & 0.018 & 0.007 & 0.400 & -0.004 & -0.200 & -0.007 & -0.360 \\
\hline HOG & 0.000 & 0.018 & -0.004 & -0.200 & -0.007 & -0.360 & -0.007 & -0.360 \\
\hline INTC & 0.000 & 0.011 & -0.009 & -0.770 & -0.033 & -2.970 & 0.000 & 0.000 \\
\hline TRP & 0.000 & 0.013 & 0.010 & 0.720 & 0.000 & -0.030 & 0.002 & 0.130 \\
\hline TRP & 0.000 & 0.013 & 0.005 & 0.370 & 0.031 & 2.320 & 0.007 & 0.530 \\
\hline LMT & 0.001 & 0.009 & 0.000 & 0.040 & 0.014 & 1.560 & 0.000 & -0.020 \\
\hline LMT & 0.001 & 0.009 & 0.004 & 0.460 & -0.014 & -1.480 & 0.003 & 0.290 \\
\hline MZDAF & -0.139 & 3.047 & 0.005 & 0.000 & -0.075 & -0.020 & 0.096 & 0.030 \\
\hline JWN & -0.001 & 0.020 & 0.018 & 0.920 & 0.040 & 2.050 & -0.001 & -0.050 \\
\hline RXN & 0.000 & 0.017 & -0.008 & -0.490 & -0.010 & -0.590 & -0.012 & -0.740 \\
\hline RXN & 0.000 & 0.017 & -0.012 & -0.710 & -0.022 & -1.330 & -0.036 & -2.160 \\
\hline TM & 0.000 & 0.010 & 0.004 & 0.400 & 0.006 & 0.620 & -0.011 & -1.110 \\
\hline TM & 0.000 & 0.010 & -0.002 & -0.190 & -0.006 & -0.610 & 0.016 & 1.580 \\
\hline TWTR & -0.001 & 0.033 & -0.019 & -0.590 & 0.016 & 0.490 & 0.018 & 0.540 \\
\hline TWTR & -0.001 & 0.033 & -0.004 & -0.110 & 0.034 & 1.050 & 0.032 & 0.970 \\
\hline WMT & 0.000 & 0.012 & -0.005 & -0.370 & 0.019 & 1.570 & -0.013 & -1.010 \\
\hline
\end{tabular}

Vol. 17, No. 1 